\title{
SISTEM PRESENSI MAHASISWA OTOMATIS PADA ZOOM MEETING MENGGUNAKAN FACE RECOGNITION DENGAN METODE CONVULITIONAL NEURAL NETWORK BERBASIS WEB
}

\author{
Sujud Satwikayana, Suryo Adi Wibowo, Nurlaily Vendyansyah \\ Program Studi Teknik Informatika S1, Fakultas Teknologi Industri \\ Institut Teknologi Nasional Malang, Jalan Raya Karanglo km 2 Malang, Indonesia \\ satwikayana@gmail.com
}

\begin{abstract}
ABSTRAK
Dalam rangka pencegahan perkembangan dan penyebaran Corona Virus Disease (COVID-19), Kementerian Pendidikan dan Kebudayaan mengeluarkan SE Mendikbud Tahun 2020 tentang Pembelajaran secara Daring dan Bekerja dari Rumah dalam rangka Pencegahan Penyebaran COVID-19. Pembelajaran secara daring dan bekerja dari rumah bagi para tenaga pendidik merupakan perubahan yang harus dilakukan untuk tetap mengajar mahasiswa. Ketika melakukan pembelajaran secara daring tentunya memerlukan media sebagai sarananya. Survei terbaru yang dilakukan oleh Lembaga Arus Survei Indonesia (ASI) terkait penggunaan media video call dalam pembelajaran daring, mayoritas publik menggunakan aplikasi Zoom (57,2 \%), disusul Google Meet (18,5\%), Cisco Webex (8,3\%), U Meet Me (5,0 \%), Microsoft Teams (2,0 \%), dan lainnya (2,2 \%). Sisanya 6,9\% mengaku tidak tahu atau tidak jawab. Presensi sangat penting untuk mengetahui dan mengontrol kehadiran peserta didik dalam proses belajar mengajar. Saat ini presensi dalam perkuliahan daring masih dilakukan secara manual. Untuk itu perlu dibuat sistem pencatatan kehadiran berbasis face recognition secara otomatis. Dalam penelitian ini metode yang digunakan untuk face recognition adalah Convolutional Neural Network (CNN). Metode diimplementasikan dengan bantuan library Keras untuk proses training data. Hasil dari penelitian ini adalah sistem berbasis web yang dapat mendeteksi wajah mahasiswa yang berpartisipasi dalam ruang Zoom meeting. Pengujian yang dilakukan kepada 10 orang relawan munggunakan model hasil training data metode $C N N$ dari total 150 kali uji coba, total benar sebanyak 138 kali dan total salah sebanyak 12 kali, menunjukkan kinerja pengenalan wajah meraih rata-rata tingkat akurasi benar sebesar 92,00\% dan salah sebesar $8,00 \%$ yang berarti sudah menghasilkan kecocokan yang baik.
\end{abstract}

\section{Kata Kunci : Pengenal Wajah, Sistem Presensi, Zoom Meeting, Convolutional Neural Network, Keras}

\section{PENDAHULUAN}

Dalam rangka pencegahan perkembangan dan penyebaran Corona Virus Disease, Kementerian Pendidikan dan Kebudayaan mengeluarkan SE Mendikbud No: 36962/MPK.A/HK/2020 Tahun 2020 tentang Pembelajaran secara Daring dan Bekerja dari Rumah dalam rangka Pencegahan Penyebaran Corona Virus Disease.

Pembelajaran secara daring dan bekerja dari rumah merupakan perubahan yang harus dilakukan untuk tetap mengajar mahasiswa. Ketika melakukan pembelajaran daring tentunya memerlukan media sebagai sarananya. Berdasarkan survei terbaru yang dilakukan oleh Lembaga Arus Survei Indonesia, terkait penggunaan media video call dalam pembelajaran daring, mayoritas publik menggunakan aplikasi Zoom (57,2 \%), disusul Google Meet (18,5 $\%)$, Cisco Webex $(8,3 \%)$, U Meet Me (5,0\%), Microsoft Teams $(2,0 \%)$, dan lainnya $(2,2 \%)$. Sisanya $6,9 \%$ mengaku tidak tahu atau tidak. Dengan periode survei pada tanggal 7 - 11 Oktober 2020 [1].

Presensi sangat penting untuk mengetahui dan mengontrol kehadiran peserta didik dalam proses belajar mengajar. Saat ini presensi dalam perkuliahan daring masih dilakukan secara manual seperti membuat google form, memanggil nama satu persatu, atau melihat nama peserta satu persatu pada saat perkuliahan daring berlangsung. Hal tersebut cukup memakan waktu yang menjadikan proses pencatatan kehadiran tersebut tidak efisien dan kemungkinan peserta didik untuk melakukan kecurangan sangat besar khususnya dalam pencatatan kehadiran menggunakan google form atau cara manual. Untuk itu perlu dibuat sistem pencatatan kehadiran berbasis face recognition secara otomatis sehingga pencatatan kehadiran dapat dilakukan secara efisien dan aman.

Salah satu metode yang cukup efisien untuk mengenali wajah adalah Convolutional Neural Network. Metode ini pernah digunakan oleh SuperVision, tim dari University of Toronto dalam kompetisi ImageNet Large Scale Visual Recognition Competition tahun 2012 dan berhasil menjadi pemenang dalam pengujian error rate dari 5 tim teratas, dengan error rate sebesar $15.3 \%$ [2].

\section{TINJAUAN PUSTAKA}

\subsection{Penelitian Terdahulu}

Pada tahun 2020, Muhammad Zufar dalam penelitiannya dengan judul "Convolutional Neural Networks untuk Pengenalan Wajah secara RealTime". Tujuan dari penelitian ini adalah mengkonstruksi dan mengimplementasikan model CNN untuk mengenali wajah manusia dari berbagai sisi secara real-time. Hasil uji coba dengan 
munggunakan konstruksi model CNN sampai kedalaman 7 lapisan dengan input dari hasil ekstraksi Extended Local Binary Pattern dengan radius 1 dan neighbor 15 menunjukkan kinerja dengan tingkat akurasi lebih dari $89 \%$ dalam \pm 2 frame per detik [3].

Pada tahun 2018, Fenti Endrianti, dkk. dalam penelitiannya dengan judul "Sistem Pencatatan Kehadiran Otomatis di Ruang Kelas Berbasis Pengenalan Wajah Menggunakan Metode Convolutional Neural Network (CNN)". Tujuan dari penelitian ini adalah menghasilkan sistem yang memiliki akurasi dan kecepatan yang lebih baik dalam proses pencatatan kehadiran otomatis. Berdasarkan hasil eksperimen didapat akurasi sebesar 93,33\%. Tingkat akurasi yang didapat bergantung kepada kondisi pengambilan citra masukan, pendeteksian wajah, serta proses klasifikasi [4].

Pada tahun 2020, Langgeng Prasetyo dalam penelitiannya dengan judul "Autentikasi Biometrik Berbasis Face Recognition Menggunakan Metode Convolutional Neural Network untuk Simulasi Barrier Gate System". Tujuan dari penelitian ini adalah membuat sistem autentikasi biometrik berbasis face recognition menggunakan metode $C N N$ berbasis face recognition untuk simulasi barrier gate system. Evaluasi hasil penelitian dengan data 100 mendapat tingkat kesalahan rata-rata 0,3205, tingkat keberhasilan sistem $94 \%$, dan waktu respon rata yang diperlukan oleh mikrokontroler $0,56217634 \mathrm{~ms}$ serta hasil evaluasi akurasi sistem dalam model confusion matrix sebesar 93,3\% [5].

Pada tahun 2020, Muhammad Arsal, dkk. dalam penelitiannya yang berjudul "Face Recognition untuk Akses Pegawai Bank Menggunakan Deep Learning Dengan Metode CNN". Pada penelitian ini, dilakukan sistem keamanan pintu akses pegawai bank dengan menggunakan face recognition. Penelitian ini berhasil menggunakan Face Recognition oleh 5 orang dataset wajah pegawai bank yang terdiri dari 70 data wajah pada masing-masing orang. Sehingga total data wajah yang digunakan 350 data wajah. Dataset tersebut dipisahkan menjadi 3 tahapan data yaitu data train, data validasi, dan data uji. Hasil dari pengujian ketiga dataset tersebut berhasil mengidentifikasi wajah yang ditangkap oleh kamera dengan keakuratan 95\% [6].

\subsection{Zoom Web Video SDK}

Zoom Web Video SDK adalah Software Developer Kit yang disediakan oleh Zoom untuk memudahkan pengembang yang ingin membuat aplikasi dengan fitur kolaborasi video Zoom.

Kegunaan dari SDK ini adalah untuk membuat aplikasi dengan UI yang dapat disesuaikan, dengan akses ke video mentah dan data audio dari Zoom. SDK inimemungkinkan pengembang pengembangan semua aplikasi video baru yang didukung oleh Zoom's core WebAssembly video framework. Basis kode dari SDK ini adalah javascript [7].

\subsection{Face Recognition}

Deteksi wajah adalah metode untuk menemukan dan mengekstrak sebuah fitur pada daerah wajah untuk keperluan pengenalan atau pendeteksian wajah [8].

Teknologi ini dapat mendeteksi wajah melalui ciri/sifat wajah dan tidak memperdulikan hal hal lainnya, seperti bangunan, pohon dan badan manusia itu sendiri. Bidang - bidang penelitian yang juga berkaitan dengan pemrosesan wajah (face processing) adalah autentikasi wajah (face authentication), lokalisasi wajah (face localization), penjejakan wajah (facetracking), dan pengenalan ekspresi wajah (facial expression recognition). Deteksi wajah merupakan salah satu tahap awal (preprocessing) yang sangat penting sebelum dilakukan proses pengenalan wajah (face recognition). Deteksi wajah dapat juga diartikan dengan deteksi benda yang spesifik. Dalam kasus ini benda yang dideteksi secara spesifik atau berupa wajah manusia yang sering disebut dengan istilah fitur. Yaitu bagian wajah manusia yang memiliki ciri khusus, seperti mata, hidung, mulut, pipi, dahi dan dagu [8].

\subsection{Convulitional Neural Network (CNN)}

Pada dasarnya algoritma CNN adalah arsitektur jaringan syaraf tiruan yang lebih efektif untuk klasfikasi citra. Konsep utama CNN sendiri terdapat pada operasi konvolusi yang dimiliknya, dimana suatu citra akan diektrasi setiap fiturnya agar terbentuk beberapa pola yang akan lebih mudah untuk diklasifikasi. Teknik ini dapat membuat fungsi pembelajaran gambar menjadi lebih efisien untuk diimplementasikan [6].

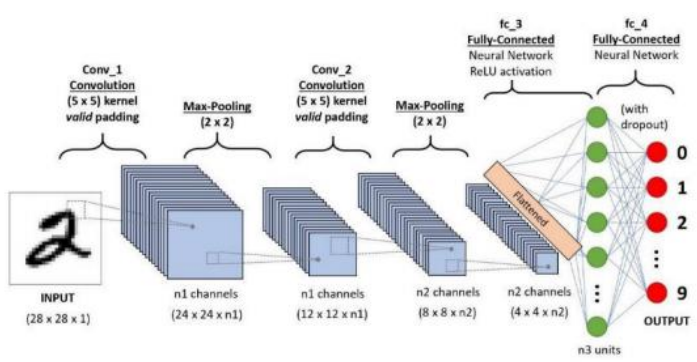

Gambar 1. Arsitektur Convolutional Neural Network

Pada Gambar 1 merupakan konsep dari CNN secara garis besar yang dibagi menjadi 3 bagian besar, yaitu input, Feature Learning, Classification. Proses input merupakan citra digital, kemudian dilakukannya proses Feature Learning untuk memproses gambar dengan model Convolutional yaitu mengambil nilai binary / vector yang terdapat pada gambar, proses aktivasi menggunakan RELu, jika proses Convolutional dan aktivasi RELu, proses Pooling merupakan proses pengumpulan, dimana semua binary / vector dikumpulkan menjadi 1 menggunakan cara Max Pooling. CNN mempunyai sejumlah layer, digunakan sebagai tahap proses 
filtering pada masing masing proses training citra image digital [6].

\subsection{Keras}

Keras adalah API deep learning yang ditulis dengan Python, berjalan di atas platform machine learning TensorFlow.

Keras dikembangkan dan fokusnya adalah mempercepat eksperimen pada proses konvolusi dan recurrent pada neural networks, maupun kombinasi antar keduanya. Pembuatan model jaringan syaraf menggunakan Keras tidak perlu menuliskan kode untuk mengekspresikan perhitungan matematisnya satu persatu. Hal ini dikarenakan Keras sudah menyediakan beberapa model dasar untuk $\mathrm{CNN}$ dan dioptimasi untuk mempermudah penelitian tentang Deep Learning. Proses komputasi menggunakan Keras berjalan lancar baik dengan menggunakan CPU maupun GPU [9].

\section{METODE PENELITIAN}

\subsection{Desain Arsitektur Sistem}

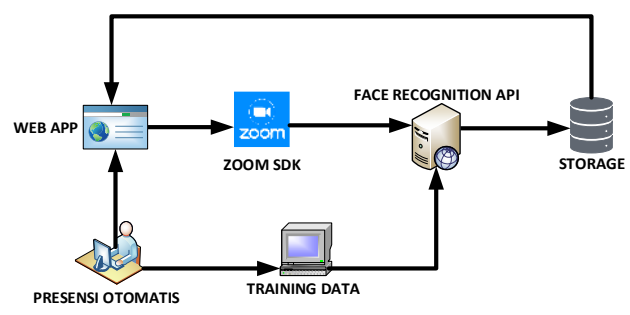

Gambar 2. Desain Arsitektur Sistem

Gambar 2 merupakan desain arsitektur sistem yang sedang digunakan, prosesnya meliputi website melakukan request ke Zoom API dengan mengirimkan data room meeting, kemudian melakukan pengambilan data citra peserta meeting sebagai inputan dalam proses face recognition. Model yang dihasilkan pada tahap training menjadi model pada sistem face recognition. Hasil dari tahap face recognition akan disimpan ke dalam penyimpanan dan ditampilkan ke dalam website sistem.

\subsection{Struktur Menu}

Dari sistem yang hendak dikembangkan dalam bentuk website, terdapat struktur menu seperti pada Gambar 3 dan Gambar 4.

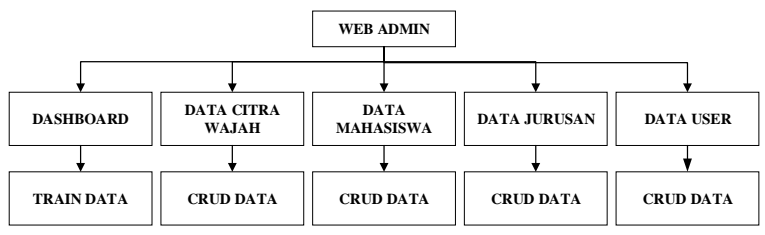

Gambar 3. Struktur menu admin

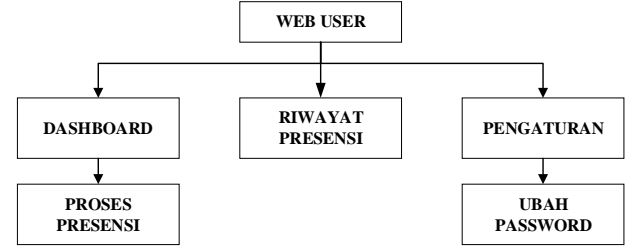

Gambar 4. Struktur menu user

Pada Gambar 3 menggambarkan tentang struktur menu dari Website yang dibuat. Terdapat menu Dashboard, Data Citra, Data Mahasiswa, Data Jurusan, dan Pengaturan. Pada menu Data Citra, Data Mahasiswa, dan Data Jurusan memiliki menu Tambah Data jika ingin menambahkan data, menu ubah data, dan hapus data. Pada menu dashboard terdapat fitur untuk admin melakukan proses train data berdasarkan data citra wajah mahasiswa.

Gambar 4 menggambarkan tentang struktur menu dari Website dengan hak akses user biasa. Terdapat menu Dashboard, Proses Presensi, Riwayat Presensi, dan Pengaturan. Pada menu Dashboard terdapat fitur untuk melakukan proses presensi. Pada menu Pengaturan terdapat menu Ubah Password yang digunakan untuk mengubah password sebelumnya.

\subsection{Diagram Blok Face Recognition}

Flowchart website sistem ini menjelaskan proses berjalananya website.

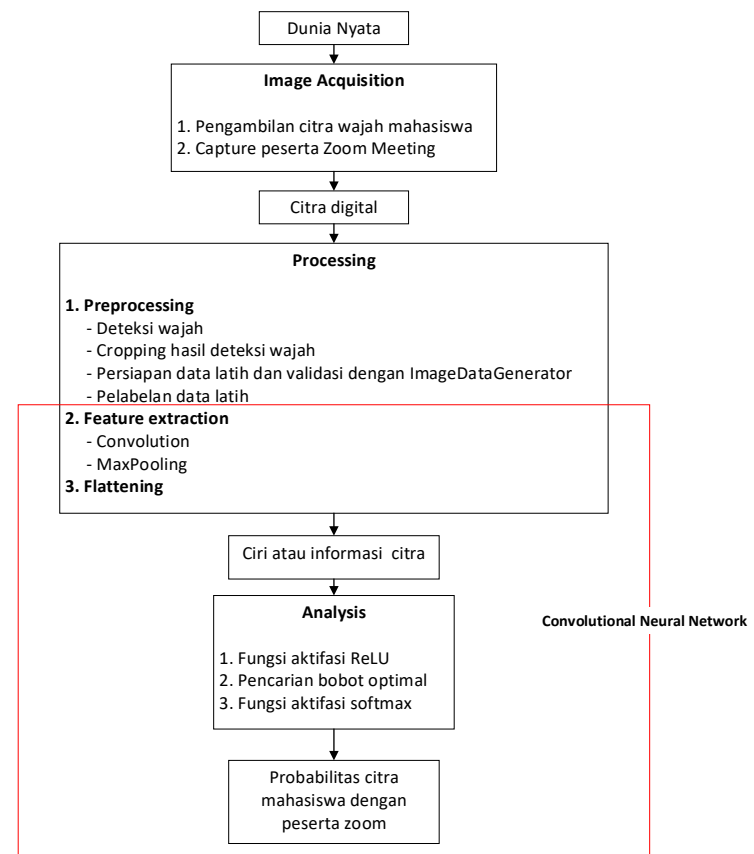

Gambar 5. Diagram blok face recognition

Gambar 5 merupakan diagram blok face recognition menggunakan pendekatan computer vision. Berawal dari dunia nyata yang kemudian dikonversi menjadi citra digital pada aktivitas Image Acquisition. Selanjutnya citra digital akan dilakukan aktivitas processing meliputi preprocessing, feature extraction, dan flattening. Dari aktivitas processing 
diperoleh informasi atau ciri dari citra digital. Informasi atau ciri ini kemudian di proses untuk dilakukan analysis yang meliputi aktifasi ReLU, pencarian bobot optimal, dan aktifasi softmax untuk mencari probabilitas. Hasil dari aktivitas analysis ini adalah probabilitas dari citra mahasiswa dengan citra peserta Zoom meeting.

\subsection{Flowchart Convolutional Neural Network}

Flowchart Convolutional Neural Network ini menjelaskan proses dari $C N N$ dalam melakukan training data dan klasifikasi.

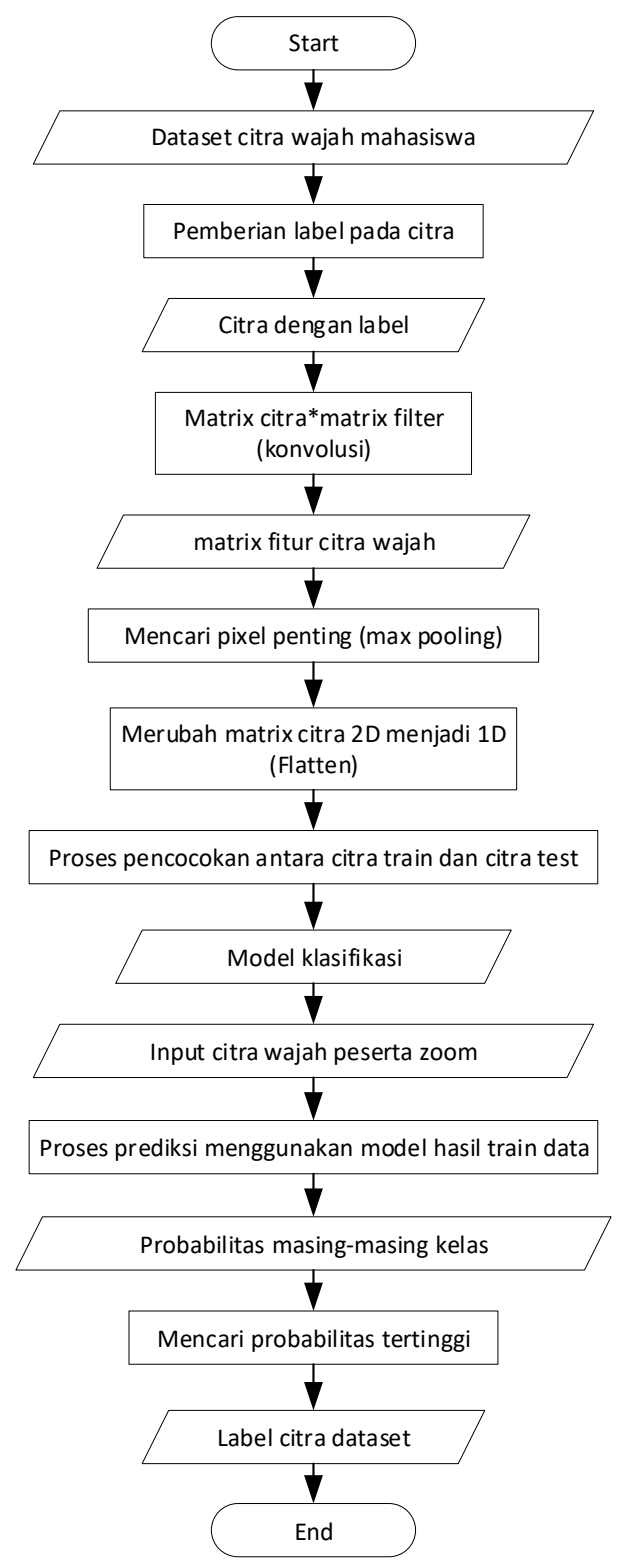

Gambar 6. Flowchart CNN

Pada Gambar 6 merupakan alur dari metode Convolutional Neural Network. Dimulai dari inputan berupa citra wajah, selanjutnya citra tersebut dilakukan proses konvolusi citra, max pooling, flatten, fully connected, fungsi aktivasi (ReLU dan
Sigmoid), pada fungsi aktivasi ini dilakukan proses klasifikasi dengan mencocokan citra inputan dengan citra dataset yang telah dilakukan proses training sebelumnya, hasil proses tersebut adalah probabilitas dari masing-masing citra. Hasil akhir berupa nama label yang terdeteksi dari probabilitas citra inputan tertinggi.

\subsection{Flowchart Proses Presensi}

Flowchart proses presensi ini menjelaskan proses berjalananya presensi yang ditinjukkan pada Gambar 7.

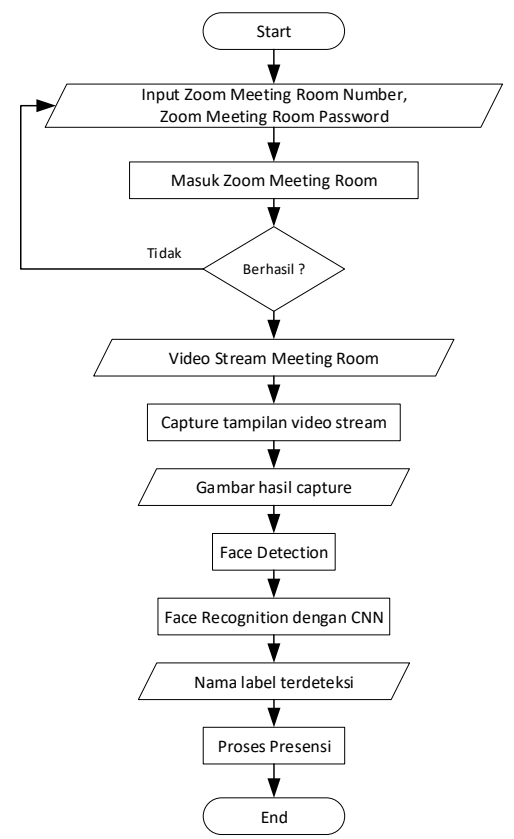

Gambar 7. Flowchart proses presensi

Gambar 7 merupakan alur dari proses presensi. Dimulai dari user memasukkan Zoom Meeting Room Number dan Zoom Meeting Room Password untuk melakukan proses masuk ke dalam ruang rapat Zoom, jika berhasil maka akan dtampilkan video stream dari meeting room. Selanjutnya video stream akan diambil gambarnya, gambar tersebut kemudian digunakan sebagai masukkan dalam proses Face Detection, hasil dari proses tersebut kemudian digunakan sebagai masukan dalam proses Face Recognition sehingga menghasilkan hasil akhir berupa output label (dalam hal ini merupakan nomor induk mahasiswa) dari citra wajah yang terdeteksi.

\section{HASIL DAN PEMBAHASAN}

\subsection{Halaman Login}

Pada halaman login terdapat proses autentikasi pengguna sistem. Dalam sistem ini terdapat dua hak akses yaitu user dan admin. Tampilan login dapat dilihat seperti Gambar 8. 


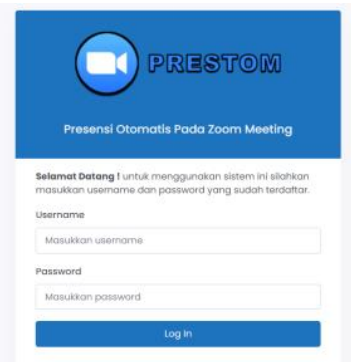

Gambar 8. Tampilan halaman login

\subsection{Implementasi Train Data dengan CNN}

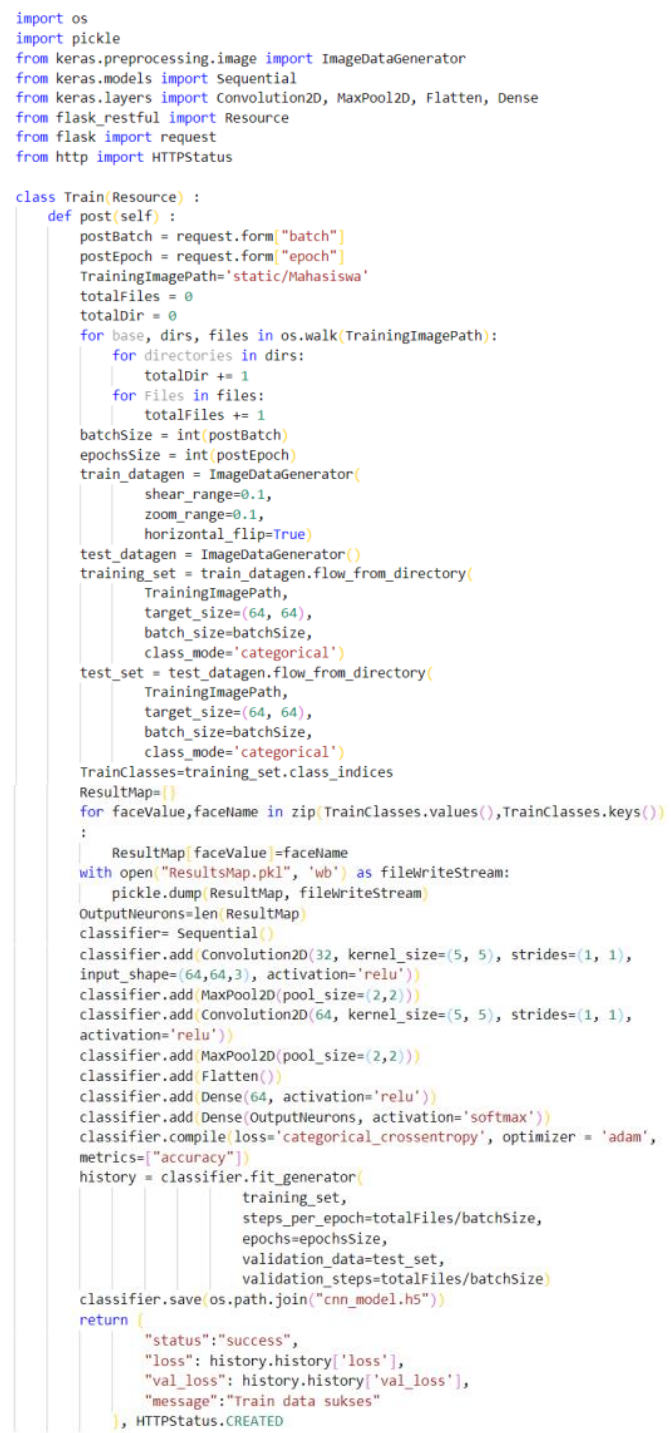

Gambar 9. Source code train data dengan CNN

Gambar 9. Merupakan tahap implementasi metode Convolutional Neural Network. Dataset yang ada dilatih menggunakan metode $\mathrm{CNN}$ untuk memperoleh model untuk face recognition. Model hasil training data disimpan pada penyimpanan internal sistem.

\subsection{Halaman Dashboard Admin}

Pada halaman dashboard admin menampilkan rangkuman informasi mengenai data pada sistem.

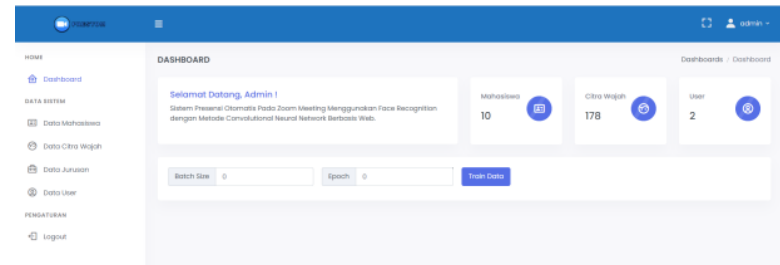

Gambar 10. Tampilan dashboard admin

Gambar 10 merupakan tampilan dari halaman dashboard admin. Terdapat informasi mengenai jumlah mahasiswa, jumlah citra wajah, dan jumlah user. Selain itu terdapat form untuk admin melakukan train data untuk proses deep learning dengan memasukkan batch size dan epoch. Hasil dari proses train data berupa grafik loss model dari proses train data, tampilan grafik seperti pada Gambar 11.

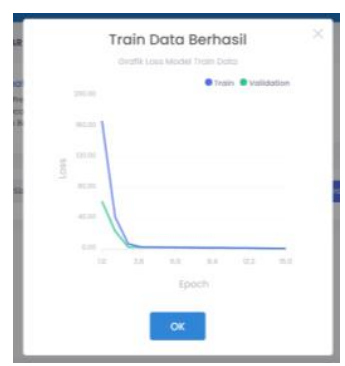

Gambar 11. Hasil proses train data

\subsection{Halaman Dashboard User}

Pada halaman dashboard user menampilkan form untuk melakukan proses presensi. Untuk melakukan proses presensi user menginputkan terlebih dahulu Meeting Number dan Meeting Password dari Zoom.

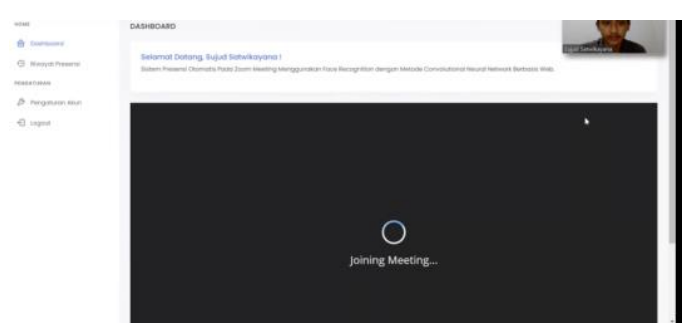

Gambar 12. Tampilan sistem masuk room meeting

Saat dilakukan proses presensi bot dari sistem akan masuk ke dalam room meeting Zoom seperti pada Gambar 12, kemudian melakukan proses capture peserta yang hadir dalam room. 


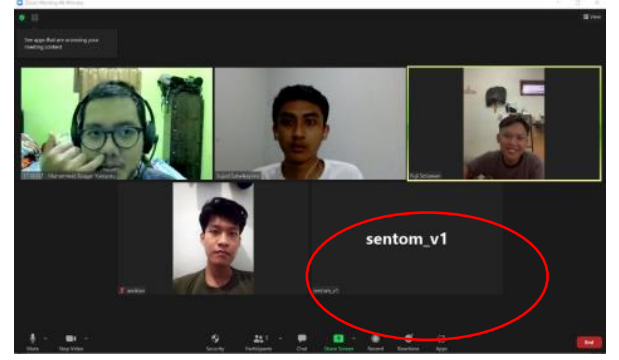

Gambar 13. Tampilan bot berada dalam room meeting

Gambar 13 menunjukkan saat bot berada dalam room meeting Zoom. Bot akan melakukan capture peserta pada room meeting dan hasil capture akan dikirim ke API face recognition untuk dilakukannya proses pengenalan wajah mahasiswa. Hasil dari proses presensi berupa daftar mahasiswa yang hadir dalam Zoom Meeting.

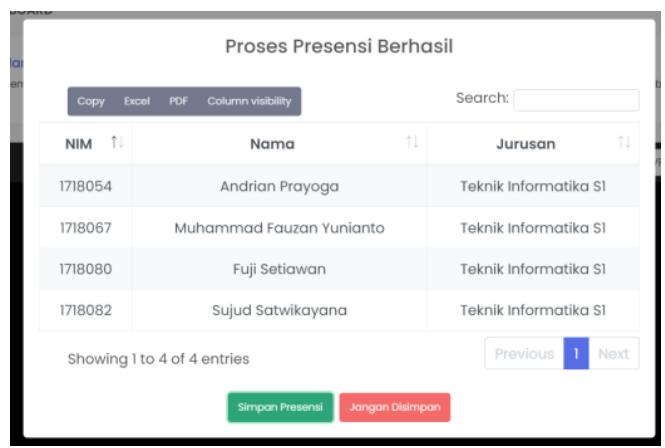

Gambar 14. Hasil proses presensi

Gambar 14 merupakan tampilan hasil proses presensi Hasil dari proses presensi berupa daftar mahasiswa yang hadir dalam Zoom Meeting. Terdapat fitur untuk report data ke dalam bentuk excel atau pdf. Jika button Simpan Presensi di klik maka data presensi akan tersimpan ke dalam data Riwayat presensi.

\subsection{Pengujian Training Model}

Dataset yang telah dikumpulkan akan dilakukan uji coba training untuk mendapatkan model pengenalan wajah dengan benar sesuai dataset yang dimasukkan. Deskripsi dari dataset untuk uji coba training model dapat dilihat pada Tabel 1 .

\section{Tabel 1. Dataset Citra Wajah}

\begin{tabular}{|c|c|l|c|}
\hline No & NIM & \multicolumn{1}{|c|}{ Nama } & $\begin{array}{c}\text { Jumlah } \\
\text { Citra }\end{array}$ \\
\hline 1. & 1718082 & Sujud Satwikayana & 36 \\
\hline 2. & 1818097 & Mutiara Sholawati & 20 \\
\hline 3. & 1718015 & Siska Wati & 20 \\
\hline 4. & 1718026 & Hyan Bening Abimanyu & 20 \\
\hline 5. & 1718054 & Andrian Prayoga & 20 \\
\hline 6. & 1718080 & Fuji Setiawan & 13 \\
\hline 7. & 1713020 & Putu Arya Pratamaartha P. & 20 \\
\hline 8. & 1713049 & Ewaldo Andreas & 20 \\
\hline 9. & 1712005 & Ketut Agung Agus Jaya & 20 \\
\hline 10. & 1718067 & Muhammad Fauzan Y. & 20 \\
\hline \multicolumn{2}{|r}{ Total } & 209 \\
\hline
\end{tabular}

Pada tahap training model, diperlukan input berupa dataset dan nama label. Dataset akan otomatis bersesuaian dengan nama label. Nama label yang bersesuain direpresentasikan sebagai deretan target bipolar. Keluaran dari proses training data adalah berupa model yang nantinya digunakan untuk proses klasifikasi wajah.

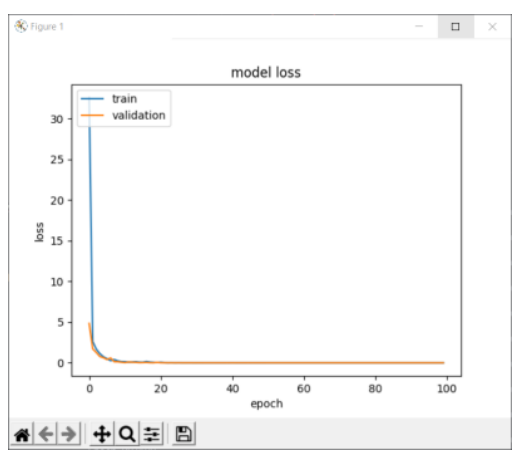

Gambar 15. Grafik loss model hasil train data

Berdasarkan Gambar 15 dapat dilihat plot train loss dan validation loss menurun ke titik stabil serta keduanya memiliki celah kecil sehingga dapat disimpulkan bahwa model hasil train data sudah memiliki kecocokan yang baik.

\subsection{Pengujian Model}

Uji coba model dilakukan dengan 6 orang relawan diantaranya terdiri dari 4 orang laki - laki dan 2 orang perempuan. Pengujian dilakukan dengan kondisi cahaya yang cukup. Hasil dari pengujian model ini dapat dilihat pada Tabel 2.

Tabel 2. Hasil Pengujian Model

\begin{tabular}{|c|c|c|c|c|c|c|}
\hline No & NIM & Benar & Salah & Total & \% Benar & \% Salah \\
\hline 1. & 1718082 & 15 & 0 & 15 & $100 \%$ & $0,00 \%$ \\
\hline 2. & 1818097 & 14 & 1 & 15 & $93,33 \%$ & $6,67 \%$ \\
\hline 3. & 1718054 & 14 & 1 & 15 & $93,33 \%$ & $6,67 \%$ \\
\hline 4. & 1718015 & 14 & 1 & 15 & $93,33 \%$ & $6,67 \%$ \\
\hline 5. & 1718026 & 13 & 2 & 15 & $86,67 \%$ & $13,33 \%$ \\
\hline 6. & 1718080 & 12 & 3 & 15 & $80 \%$ & $20,00 \%$ \\
\hline 7. & 1713020 & 14 & 1 & 15 & $93,33 \%$ & $6,67 \%$ \\
\hline 8. & 1713049 & 14 & 1 & 15 & $93,33 \%$ & $6,67 \%$ \\
\hline 9. & 1712005 & 14 & 1 & 15 & $93,33 \%$ & $6,67 \%$ \\
\hline 10. & 1718067 & 14 & 1 & 15 & $93,33 \%$ & $6,67 \%$ \\
\hline \multicolumn{2}{|r|}{ Total } & 138 & 12 & 150 & & \\
\hline \multicolumn{2}{|c|}{ Akurasi } & $92 \%$ & $8 \%$ & $100 \%$ & & \\
\hline
\end{tabular}

Pada Tabel 2 dapat dilihat dari total 150 kali uji coba, total benar sebanyak 138 kali dan total salah sebanyak 12 kali. Berdasarkan hasil tersebut didapatkan akurasi benar sebesar $92 \%$.

Berdasarkan dataset citra wajah dan dari relawan sebanyak 10 mahasiswa untuk melakukan pengujian model dapat disimpulkan bahwa semakin banyak dataset untuk training data maka semakin kecil persentase kesalahan terjadi.

\subsection{Pengujian Berdasarkan Identitas Cahaya}

Pengujian ini dilakukan berdasarkan kondisi intensitas cahaya. Hasil dari pengujian pada Tabel 3. 
Tabel 3. Pengujian Berdasarkan Identitas Cahaya

\begin{tabular}{|c|c|c|c|}
\hline No & Gambar & Lux & Hasil Deteksi \\
\hline 1. & & 2530 & Benar \\
\hline 2. & 250 & Benar \\
\hline 3. & 150 & Benar \\
\hline 4. & & 35 & Benar \\
\hline 5. & & 3 & Salah \\
\hline
\end{tabular}

Berdasarkan Tabel 3 dapat dilihat pada uji coba ke-5 dengan nilai identitas cahaya sebesar 3 lux citra wajah tidak dapat dikenali. Dengan demikian dapat disimpulkan intensitas cahaya juga berpengaruh pada proses pendeteksian.

\subsection{Pengujian Black Box}

Pengujian Black Box berfokus pada spesifikasi fungsional dari perangkat lunak.

Tabel 4. Pengujian Proses Login

\begin{tabular}{|c|c|c|c|c|}
\hline No & Input & $\begin{array}{c}\text { Hasil Yang } \\
\text { Diharapkan }\end{array}$ & $\begin{array}{c}\text { Hasil } \\
\text { Sistem }\end{array}$ & $\begin{array}{c}\text { Kesimp } \\
\text { ulan }\end{array}$ \\
\hline 1 & $\begin{array}{c}\text { username:admin, } \\
\text { password: admin }\end{array}$ & $\begin{array}{c}\text { Ke halaman } \\
\text { dashboard } \\
\text { admin }\end{array}$ & $\begin{array}{c}\text { Ke page } \\
\text { dashboar } \\
\text { d admin }\end{array}$ & Sesuai \\
\hline 2 & $\begin{array}{c}\text { username:1718082, } \\
\text { password: } 123456\end{array}$ & $\begin{array}{c}\text { Ke halaman } \\
\text { dashboard } \\
\text { user }\end{array}$ & $\begin{array}{c}\text { Ke page } \\
\text { dashboar } \\
\text { d user }\end{array}$ & Sesuai \\
\hline
\end{tabular}

Tabel 5. Pengujian Dashboard Admin

\begin{tabular}{|c|c|c|c|c|}
\hline No & Input & $\begin{array}{c}\text { Hasil Yang } \\
\text { Diharapkan }\end{array}$ & $\begin{array}{c}\text { Hasil } \\
\text { Sistem }\end{array}$ & Kesimpulan \\
\hline 1. & $\begin{array}{l}\text { Menu } \\
\text { dashboard }\end{array}$ & $\begin{array}{c}\text { Tampil info } \\
\text { data dan form } \\
\text { untuk train } \\
\text { data }\end{array}$ & $\begin{array}{c}\text { Tampil } \\
\text { info data } \\
\text { dan form } \\
\text { untuk } \\
\text { train data }\end{array}$ & Sesuai \\
\hline 2. & $\begin{array}{l}\text { Train data } \\
\text { Batch Size } \\
: 32, \text { Epoch } \\
: 100\end{array}$ & $\begin{array}{c}\text { Pop up hasil } \\
\text { training data }\end{array}$ & $\begin{array}{c}\text { Pop up } \\
\text { hasil } \\
\text { training } \\
\text { data }\end{array}$ & Sesuai \\
\hline
\end{tabular}

Tabel 6. Pengujian Pengolahan Data Mahasiswa

\begin{tabular}{|c|c|c|c|c|}
\hline No & Input & $\begin{array}{l}\text { Hasil Yang } \\
\text { Diharapkan }\end{array}$ & $\begin{array}{c}\text { Hasil } \\
\text { Sistem }\end{array}$ & $\begin{array}{c}\text { Kesimpul } \\
\text { an }\end{array}$ \\
\hline 1. & $\begin{array}{l}\text { Menu data } \\
\text { mahasiswa }\end{array}$ & $\begin{array}{l}\text { Tampil data } \\
\text { mahasiswa }\end{array}$ & $\begin{array}{c}\text { Tampil } \\
\text { data } \\
\text { mahasiswa }\end{array}$ & Sesuai \\
\hline 2. & $\begin{array}{l}\text { Tambah data } \\
\text { mahasiswa } \\
\text { Jurusan: } \\
\text { Informatika, } \\
\text { NIM } \\
: 1718082 \text {, } \\
\text { Nama : Sujud }\end{array}$ & $\begin{array}{c}\text { Data } \\
\text { tersimpan dan } \\
\text { tampil pesan } \\
\text { berhasil } \\
\text { menambah } \\
\text { data }\end{array}$ & $\begin{array}{c}\text { Data } \\
\text { tersimpan } \\
\text { dan tampil } \\
\text { pesan } \\
\text { berhasil } \\
\text { menambah } \\
\text { data } \\
\end{array}$ & Sesuai \\
\hline 3. & $\begin{array}{l}\text { Edit data } \\
\text { mahasiswa } \\
\text { Jurusan: } \\
\text { Informatika, } \\
\text { NIM }\end{array}$ & $\begin{array}{c}\text { Data } \\
\text { tersimpan dan } \\
\text { tampil pesan } \\
\text { data berhasil } \\
\text { dirubah }\end{array}$ & $\begin{array}{c}\text { Data } \\
\text { tersimpan } \\
\text { dan tampil } \\
\text { pesan data } \\
\text { berhasil }\end{array}$ & Sesuai \\
\hline
\end{tabular}

\begin{tabular}{|c|l|c|c|c|}
\hline & $\begin{array}{l}: 1718082, \\
\text { Nama : Agus }\end{array}$ & & dirubah & \\
\hline \multirow{4}{*}{4.} & $\begin{array}{l}\text { Hapus data } \\
\text { Mahasiswa } \\
\text { Klik tombol } \\
\text { hapus }\end{array}$ & $\begin{array}{c}\text { Muncul } \\
\text { peringatan, } \\
\text { jika pilih “ya" } \\
\text { maka data } \\
\text { terhapus }\end{array}$ & $\begin{array}{c}\text { Muncul } \\
\text { peringatan, } \\
\text { jika pilih } \\
\text { "ya" maka } \\
\text { data } \\
\text { terhapus }\end{array}$ & Sesuai \\
\hline
\end{tabular}

Tabel 7. Pengujian Pengolahan Data Citra Wajah

\begin{tabular}{|c|c|c|c|c|}
\hline No & Input & $\begin{array}{l}\text { Hasil Yang } \\
\text { Diharapkan }\end{array}$ & $\begin{array}{l}\text { Hasil } \\
\text { Sistem }\end{array}$ & Kesimpulan \\
\hline 1. & $\begin{array}{c}\text { Menu data } \\
\text { citra } \\
\text { wajah }\end{array}$ & $\begin{array}{l}\text { Tampil data } \\
\text { citra wajah } \\
\text { mahasiswa }\end{array}$ & $\begin{array}{c}\text { Tampil } \\
\text { data citra } \\
\text { wajah } \\
\text { mahasiswa }\end{array}$ & Sesuai \\
\hline 2. & $\begin{array}{l}\text { Tombol } \\
\text { detail citra } \\
\text { wajah }\end{array}$ & $\begin{array}{l}\text { Tampil data } \\
\text { citra dari } \\
\text { mahasiswa }\end{array}$ & $\begin{array}{c}\text { Tampil } \\
\text { data citra } \\
\text { dari } \\
\text { mahasiswa }\end{array}$ & Sesuai \\
\hline 3. & $\begin{array}{c}\text { Tambah } \\
\text { data citra } \\
\text { wajah } \\
\text { NIM: } \\
\text { 1718082, } \\
\text { Citra } \\
\text { Wajah : } \\
\text { sujud.jpeg }\end{array}$ & $\begin{array}{c}\text { Data } \\
\text { tersimpan } \\
\text { dan tampil } \\
\text { pesan } \\
\text { berhasil } \\
\text { menambah } \\
\text { data }\end{array}$ & $\begin{array}{c}\text { Data } \\
\text { tersimpan } \\
\text { dan tampil } \\
\text { pesan } \\
\text { berhasil } \\
\text { menambah } \\
\text { data }\end{array}$ & Sesuai \\
\hline
\end{tabular}

Tabel 8. Pengujian Pengolahan Data Jurusan

\begin{tabular}{|c|c|c|c|c|}
\hline No & Input & $\begin{array}{c}\text { Hasil Yang } \\
\text { Diharapkan }\end{array}$ & Hasil Sistem & Kesimpulan \\
\hline 1. & $\begin{array}{l}\text { Menu data } \\
\text { jurusan }\end{array}$ & $\begin{array}{c}\text { Menampilkan } \\
\text { data jurusan }\end{array}$ & $\begin{array}{c}\text { Menampilkan } \\
\text { data jurusan }\end{array}$ & Sesuai \\
\hline 2. & $\begin{array}{c}\text { Tambah } \\
\text { data } \\
\text { jurusan } \\
\text { Kode : } 18, \\
\text { Jurusan : } \\
\text { Informatika } \\
\text { S1 }\end{array}$ & $\begin{array}{c}\text { Data } \\
\text { tersimpan, } \\
\text { tampil pesan } \\
\text { berhasil } \\
\text { menambah } \\
\text { data }\end{array}$ & $\begin{array}{c}\text { Data } \\
\text { tersimpan, } \\
\text { tampil pesan } \\
\text { berhasil } \\
\text { menambah } \\
\text { data }\end{array}$ & Sesuai \\
\hline 3. & $\begin{array}{l}\text { Edit data } \\
\text { jurusan } \\
\text { Kode: } 18 \text {, } \\
\text { Nama } \\
\text { Jurusan : } \\
\text { Teknik S1 } \\
\end{array}$ & $\begin{array}{c}\text { Data } \\
\text { tersimpan } \\
\text { dan tampil } \\
\text { pesan data } \\
\text { berhasil } \\
\text { dirubah } \\
\end{array}$ & $\begin{array}{c}\text { Data } \\
\text { tersimpan } \\
\text { dan tampil } \\
\text { pesan data } \\
\text { berhasil } \\
\text { dirubah } \\
\end{array}$ & Sesuai \\
\hline 4. & $\begin{array}{c}\text { Hapus } \\
\text { data } \\
\text { jurusan } \\
\text { Klik } \\
\text { tombol } \\
\text { hapus }\end{array}$ & $\begin{array}{c}\text { Muncul } \\
\text { peringatan, } \\
\text { jika pilih } \\
\text { “ya” maka } \\
\text { data terhapus }\end{array}$ & $\begin{array}{c}\text { Muncul } \\
\text { peringatan, } \\
\text { jika pilih } \\
\text { “ya" maka } \\
\text { data terhapus }\end{array}$ & Sesuai \\
\hline
\end{tabular}

Tabel 9. Pengujian Data User

\begin{tabular}{|c|c|c|c|c|}
\hline No & Input & $\begin{array}{c}\text { Hasil Yang } \\
\text { Diharapkan }\end{array}$ & Hasil Sistem & Kesimpulan \\
\hline 1. & $\begin{array}{c}\text { Menu } \\
\text { data user }\end{array}$ & $\begin{array}{c}\text { Menampilkan } \\
\text { data user }\end{array}$ & $\begin{array}{c}\text { Menampilkan } \\
\text { data user }\end{array}$ & Sesuai \\
\hline \multirow{2}{*}{2.} & $\begin{array}{c}\text { Tambah } \\
\text { data user } \\
\text { Nama: } \\
\text { Sujud, } \\
\text { Username } \\
\text { 1718082, } \\
\text { Password : } \\
\text { tersimpan } \\
\text { dan tampil } \\
\text { pesan } \\
\text { berhasil } \\
\text { menambah } \\
\text { data }\end{array}$ & $\begin{array}{c}\text { Data } \\
\text { dersimpan } \\
\text { dampil } \\
\text { pesan } \\
\text { berhasil } \\
\text { menambah } \\
\text { data }\end{array}$ & Sesuai \\
\hline 3. & $\begin{array}{c}\text { Hapus } \\
\text { data user } \\
\text { Klik } \\
\text { tombol } \\
\text { hapus }\end{array}$ & $\begin{array}{c}\text { Muncul } \\
\text { peringatan, } \\
\text { jika pilih } \\
\text { "ya" maka } \\
\text { data terhapus }\end{array}$ & $\begin{array}{c}\text { Muncul } \\
\text { peringatan, } \\
\text { jika pilih } \\
\text { "ya" maka } \\
\text { data terhapus }\end{array}$ & Sesuai \\
\hline
\end{tabular}


Tabel 10. Pengujian Dashboard User

\begin{tabular}{|c|c|c|c|c|}
\hline No & Input & $\begin{array}{c}\text { Hasil Yang } \\
\text { Diharapkan }\end{array}$ & Hasil Sistem & Kesimpulan \\
\hline 1. & $\begin{array}{c}\text { Menu } \\
\text { dashboard }\end{array}$ & $\begin{array}{c}\text { Tampil form } \\
\text { untuk } \\
\text { presensi } \\
\text { otomatis }\end{array}$ & $\begin{array}{c}\text { Tampil form } \\
\text { untuk } \\
\text { presensi } \\
\text { otomatis }\end{array}$ & Sesuai \\
\hline 2. & $\begin{array}{c}\text { Form } \\
\text { Presensi } \\
\text { Meeting } \\
\text { Number: } \\
\text { 88529386857, } \\
\text { Password: } \\
\text { UzZyZ0d }\end{array}$ & $\begin{array}{l}\text { Pop up hasil } \\
\text { presensi } \\
\text { berupa data } \\
\text { mahasiswa } \\
\text { yang } \\
\text { terdeteksi }\end{array}$ & $\begin{array}{l}\text { Pop up hasil } \\
\text { presensi } \\
\text { berupa data } \\
\text { mahasiswa } \\
\text { yang } \\
\text { terdeteksi }\end{array}$ & Sesuai \\
\hline
\end{tabular}

Tabel 11. Pengujian Riwayat Presensi

\begin{tabular}{|c|c|c|c|c|}
\hline No & Input & $\begin{array}{c}\text { Hasil Yang } \\
\text { Diharapkan }\end{array}$ & $\begin{array}{c}\text { Hasil } \\
\text { Sistem }\end{array}$ & Kesimpulan \\
\hline 1. & $\begin{array}{c}\text { Menu } \\
\text { data } \\
\text { riwayat } \\
\text { presensi }\end{array}$ & $\begin{array}{c}\text { Tampil data } \\
\text { riwayat } \\
\text { presensi }\end{array}$ & $\begin{array}{c}\text { Tampil } \\
\text { data } \\
\text { riwayat } \\
\text { presensi }\end{array}$ & Sesuai \\
\hline 2. & $\begin{array}{c}\text { Tombol } \\
\text { detail } \\
\text { riwayat } \\
\text { presensi }\end{array}$ & $\begin{array}{c}\text { Tampil detail } \\
\text { data riwayat } \\
\text { presensi }\end{array}$ & $\begin{array}{c}\text { Tampil } \\
\text { detail data } \\
\text { riwayat } \\
\text { presensi }\end{array}$ & Sesuai \\
\hline
\end{tabular}

Tabel 12. Pengujian Pengaturan Akun

\begin{tabular}{|c|c|c|c|c|}
\hline No & Input & $\begin{array}{c}\text { Hasil Yang } \\
\text { Diharapkan }\end{array}$ & $\begin{array}{c}\text { Hasil } \\
\text { Sistem }\end{array}$ & Kesimpulan \\
\hline \multirow{7}{*}{1.} & Nama & Data & \\
& Lengkap: & Data & Data & \\
& Sujud, & tersimpan & \\
& Password & dan tampil & tampil & \multirow{2}{*}{ Sesuai } \\
& Baru: & pesan data & pesan & \\
& sujud12345, & berhasil & data & \\
& Konfirm: & dirubah & berhasil & \\
& dirubah & \\
\hline
\end{tabular}

Berdasarkan hasil dari pengujian black box pada Tabel 4, Tabel 5, Tabel 6, Tabel 7, Tabel 8, Tabel 9, Tabel 10, Tabel 11, dan Tabel 12 antara hasil yang diharapkan dengan hasil dari sistem secara keseluruhan memperoleh hasil yang sesuai, sehingga dapat ditarik kesimpulan bahwa sistem ini tidak terdapat kesalahan pada spesifikasi fungsional dan siap digunakan oleh pengguna.

\subsection{Pengujian Fungsional Aplikasi}

Pengujian fungsional aplikasi pada penelitian ini dengan dilakukannya menguji Website terhadap web browser yang bertujuan untuk mengetahui apakah halaman Website yang dibuat dapat menampilkan keseluruhan data sesuai dengan perancangan bukan hanya pada satu web browser yang sering digunakan pada umumnya.

Tabel 4. Hasil pengujian fungsionalitas aplikasi

\begin{tabular}{|c|l|c|c|c|}
\hline \multirow{2}{*}{ No } & \multicolumn{2}{|c|}{ Aspek } & \multicolumn{3}{|c|}{ Web Browser } \\
\cline { 3 - 5 } & Chrome & $\begin{array}{l}\text { Microsoft } \\
\text { Edge }\end{array}$ & Firefox \\
\hline 1. & Login & $\checkmark$ & $\checkmark$ & $\checkmark$ \\
\hline 2. & Dashboard & $\checkmark$ & $\checkmark$ & $\checkmark$ \\
\hline 3. & $\begin{array}{l}\text { Halaman Data } \\
\text { Mahasiswa }\end{array}$ & $\checkmark$ & $\checkmark$ & $\checkmark$ \\
\hline 4. & $\begin{array}{l}\text { Halaman Citra } \\
\text { Wajah }\end{array}$ & $\checkmark$ & $\checkmark$ & $\checkmark$ \\
\hline 5. & $\begin{array}{l}\text { Halaman Data } \\
\text { Jurusan }\end{array}$ & $\checkmark$ & $\checkmark$ & $\checkmark$ \\
\hline
\end{tabular}

\begin{tabular}{|c|l|c|c|c|}
\hline 6. & Halaman Data User & $\checkmark$ & $\checkmark$ & $\checkmark$ \\
\hline 7. & $\begin{array}{l}\text { Halaman Riwayat } \\
\text { Presensi }\end{array}$ & $\checkmark$ & $\checkmark$ & $\checkmark$ \\
\hline 8. & $\begin{array}{l}\text { Halaman Setting } \\
\text { Akun }\end{array}$ & $\checkmark$ & $\checkmark$ & $\checkmark$ \\
\hline 9. & Train Data & $\checkmark$ & $\checkmark$ & $\checkmark$ \\
\hline 10. & Proses Presensi & $\checkmark$ & $\checkmark$ & $\checkmark$ \\
\hline
\end{tabular}

Keterangan:

$\checkmark$ : Berhasil

$\mathbf{x}$ : Tidak Berhasil

Tabel 4 Merupakan hasil dari pengujian menggunakan web browser. Aplikasi yang dibuat dapat berjalan dengan baik pada web browser Google Chrome, Microsoft Edge, dan Firefox.

\subsection{Pengujian Pengguna}

Pengujian pengguna dilakukan untuk melihat kelayakan dari aplikasi yang telah dibuat. Pengujian ini dilakukan dengan mengisi kuesioner yang dibuat untuk melakukan pengujian. Kuesioner yang disebarkan sebanyak 23 kuesioner kepada responden diantaranya 21 pengujian hak akses pengguna biasa dan 2 pengujian hak akses admin. Hasil dari pengujian yang dilakukan dapat dilihat pada Tabel 5 .

Tabel 5. Hasil pengujian pengguna

\begin{tabular}{|l|l|c|c|c|c|}
\hline \multirow{2}{*}{ No } & \multicolumn{1}{|c|}{ Pertanyaan } & \multicolumn{4}{|c|}{ Jawaban } \\
\cline { 2 - 6 } & SS & S & TS & STS \\
\hline 1. & $\begin{array}{l}\text { Sistem Presensi } \\
\text { Mahasiswa Otomatis pada } \\
\text { Zoom Meeting } \\
\text { menggunakan Face } \\
\text { Recognition dengan } \\
\text { Metode Convolutional } \\
\text { Neural Network Berbasis } \\
\text { Web mudah digunakan. }\end{array}$ & 17 & 6 & 0 & 0 \\
\hline 2. & $\begin{array}{l}\text { Fitur dari siste ini mudah } \\
\text { di pahami. }\end{array}$ & 17 & 6 & 0 & 0 \\
\hline 3. & $\begin{array}{l}\text { Informasi yang di sajikan } \\
\text { pada aplikasi ini mudah } \\
\text { dipahami. }\end{array}$ & 17 & 6 & 0 & 0 \\
\hline 4. & $\begin{array}{l}\text { Warna tombol, jenis font, } \\
\text { dan warna font aplikasi } \\
\text { terlihat jelas dan sesuai. }\end{array}$ & 16 & 5 & 2 & 0 \\
\hline Total & 67 & 23 & 2 & 0 \\
\hline Total Keseluruhan & \multicolumn{3}{|c|}{92} \\
\hline
\end{tabular}

Keterangan:

SS : Sangat Setuju S : Setuju

TS : Tidak Setuju STS : Sangat Tidak Setuju

Berdasarkan Tabel 3 maka dapat disimpulkan, dari pengujian yang ditujukan kepada 23 pengguna menunjukan bahwa $72,83 \%$ menyatakan Sangat Setuju, 25\% menyatakan Setuju, 2,17\% menyatakan Tidak Setuju dan 0\% menyatakan Sangat Tidak Setuju.

\section{KESIMPULAN DAN SARAN}

\subsection{Kesimpulan}

Berdasarkan beberapa pengujian yang telah dilakukan didapatkan kesimpulan : 
1. Hasil pengujian model dengan menggunakan data dari relawan sebanyak 10 mahasiswa untuk melakukan pengujian model, dari total 150 kali uji coba, total benar sebanyak 138 kali dan total salah sebanyak 12 kali. Berdasarkan hasil tersebut didapatkan akurasi benar sebesar 92,00 $\%$. Dapat ditarik kesimpulan bahwa model untuk face recognition ini sudah menghasilkan kecocokan yang baik.

2. Hasil pengujian training data dengan menggunakan dataset mahasiswa sebanyak 10 mahasiswa dengan total citra wajah sebanyak 209 citra didapat model hasil training data yang sudah memiliki kecocokan yang baik dilihat dari plot train loss dan validation loss menurun ke titik stabil serta keduanya memiliki celah kecil.

3. Hasil pengujian model menggunakan data dari relawan sebanyak 10 mahasiswa untuk melakukan pengujian model dapat disimpulkan bahwa semakin banyak dataset untuk training data maka semakin kecil persentase kesalahan terjadi.

4. Hasil pengujian model dengan menggunakan data citra yang diambil dalam kondisi cahaya yang berbeda, dari 5 kali percobaan dengan nilai identitas cahaya sebesar 3 lux citra wajah tidak dapat dikenali. Dengan demikian dapat disimpulkan intensitas cahaya juga berpengaruh pada proses pendeteksian, karena semakin baik intensitas cahaya semakin baik sistem dalam mengenali wajah.

5. Hasil pengujian black box menunjukan antara hasil yang diharapkan dengan hasil dari sistem secara keseluruhan memperoleh hasil yang sesuai, sehingga dapat ditarik kesimpulan bahwa sistem ini tidak terdapat kesalahan pada spesifikasi fungsional.

6. Hasil pengujian fungsional menunjukkan hasil $100 \%$, yang artinya semua fitur program dapat berjalan sesuai dengan fungsinya walaupun di browser berbeda.

7. Hasil pengujian pengguna menggunakan kuesioner yang ditujukan kepada 23 pengguna menunjukan bahwa 72,83\% menyatakan Sangat Setuju, 25\% menyatakan Setuju, 2,17\% menyatakan Tidak Setuju dan $0 \%$ menyatakan Sangat Tidak Setuju.

\subsection{Saran}

Berdasarkan penelitian yang telah dilakukan, maka penulis dapat memberikan saran-saran untuk pengembangan selanjutnya antar lain :
1. Agar model untuk face recognition menjadi lebih akurat lagi diharapkan menggunakan lebih banyak dataset untuk proses training data.

2. Untuk mengumpulkan dataset agar lebih mudah, diharapkan dibuat fitur untuk ekstraksi dataset pada sistem dengan inputan berupa video.

3. Untuk menambah keakuratan dapat melakukan pengembangan sistem dengan mengintegrasikan antara face recognition dengan sistem biometrik lainnya.

\section{DAFTAR PUSTAKA}

[1] PT. Arus Survei Indonesia, "Persepsi Publik terhadap Program Bantuan Kuota Internet Kemendikbud RI Tahun 2020," Jakarta, 2020.

[2] A. Krizhevsky, I. Sutskever and G. E. Hinton, "ImageNet Classification with Deep Convolutional," Communications of the ACM, vol. 60, no. 6, pp. 84-90, 2017.

[3] M. Zufar, "Convolutional Neural Networks untuk Pengenalan Wajah Secara Real-time," Doctoral dissertation, Institut Technology Sepuluh Nopember, 2016.

[4] F. Endrianti, W. Setiawan and Y. Wihardi, "Sistem Pencatatan Kehadiran Otomatis di Ruang Kelas Berbasis Pengenalan Wajah Menggunakan Metode Convolutional Neural Network (CNN)," JATIKOM: Jurnal Teori dan Aplikasi Ilmu Komputer, vol. 1, no. 1, pp. 40-44, 2018.

[5] M. L. Prasetyo, "AUTENTIKASI BIOMETRIK BERBASIS FACE RECOGNITION," Doctoral dissertation, UIN Sunan Ampel Surabaya, 2020.

[6] M. Arsal, B. A. Wardijono and D. Anggraini, "Face Recognition Untuk Akses Pegawai Bank Menggunakan Deep Learning," JURNAL NASIONAL TEKNOLOGI DAN SISTEM INFORMASI, vol. 6, no. 1, pp. 55-63, 2020.

[7] Zoom, "Web Video SDK - Zoom SDK," Zoom Video Communications, [Online]. Available: https://marketplace.zoom.us/docs/sdk/video/web . [Accessed 15 Mei 2021].

[8] M. N. Inrawansyah, "IMPLEMENTASI FACE DETECTION MENGGUNAKAN METODE VIOLA JONES UNTUK MEMBANTU MEMPERMUDAH PROSES COUNTER PENGUNJUNG GEDUNG," JATI (Jurnal Mahasiswa Teknik Informatika), vol. 1, no. 1, pp. 8-16, 2017

[9] T. Shafira, "IMPLEMENTASI CONVOLUTIONAL NEURAL NETWORKS UNTUK KLASIFIKASI CITRA TOMAT MENGGUNAKAN KERAS," Doctoral dissertation, Universitas Islam Indonesia, 2018 